\title{
More suitors from abroad
}

\section{London}

IN the latest in a series of long-term investments by overseas drug companies in UK university-based research, Eisai, an expanding Japanese company, last week announced that it will spend $£ 50$ million over the next 15 years to set up a new neurosciences research centre at University College London (UCL).

The move has been welcomed by the UK scientific community but at the same time has reawakened criticism of British companies, which show little sign of emulating their foreign competitors' large-scale investment in universities.

The centre will be housed in a new building, to open in 1992, concentrating on basic research into the factors underlying diseases of the central nervous system such as Alzheimer's and Parkinson's. Short-term commercial benefits are unlikely, but any patent rights will be held by Eisai. The centre's 30 staff will be Eisai employees, and so will need approval before they can publish research data. But Derek Roberts, provost of University College London, does not expect any problems, because Eisai has a good record of allowing employees freedom to publish.

Roberts points out that Eisai chose to site the new centre at UCL, rather than at a less expensive 'green field' site, because it wishes to gain from the exchange of ideas with other academics on the campus. A restrictive policy of commercial confidentiality would soon subvert this aim.

Professor Denis Noble, president of the academic pressure group Save British Science, says the Eisai investment is part of a welcome trend towards closer relationships between university researchers and overseas companies. But he says Eisai's "enlightened" attitude is not shared by British companies, which prefer to use universities strictly for contract research aimed at specific and short-term goals. US CANCER EPIDEMIOLOGY

\section{No Sellafield effect in US study?}

\section{Washington}

A Two-year study to be released this week has found no increased incidence in cancer mortality around nuclear facilities in $\mathbf{1 0 7}$ US counties, but researchers warn that the resolution of the data may be too coarse to draw firm conclusions.

The study, conducted by a team at the National Cancer Institute (NCI) led by John Boice, was begun in 1987, after a similar British study published in this journal suggested that there might be a higher incidence of childhood leukaemia near nuclear installations (see Nature 329, 499; 1987). Subsequent studies, including one published this year that provided evidence of a cluster of cases of childhood leukaemia in the vicinity of the Sellafield nuclear plant (see Nature 343, 679; 1990), have raised more questions than they have answered.

The NCI study seems likely to be no exception. "From the data at hand, there was no convincing evidence of any increased risk of death from any of the cancers we surveyed due to living near nuclear facilities", Boice stated last week. But he also said that the size of the areas from which data were collected may be too large to detect small pockets of cancer immediately around nuclear plants.

In the 1987 British study, David Forman and colleagues from the Imperial Cancer Research Fund Cancer Epidemiology and Clinical Trials Unit, Oxford, used local authority areas (LAAs) as the units of geographic location of the surveyed populations. Forman's team used only LAAs with at least one-third of their population living within 10 miles of a nuclear facility. Many of the LAAs had two-thirds of their population living within six miles of the installation.

The US counties used in the NCI study are much larger. The NCI team used county mortality records, rather than those located by zip code (which tend to represent much smaller areas), because they were the only complete record to which the researchers had access at the time. "We recognized that it was a problem, but [counties] were the smallest unit for which death data was available", says team member B.J. Stone. "If we had had a choice, we would have gone to censustracked data." For childhood leukaemia, the NCI study found that mortality risks were slightly higher before the start-up of a nuclear plant in the county than after. For other forms of childhood cancer, the reverse was true. But in both cases, the change in risk is so small (1.08 to 1.03 in the first case, 0.94 to 0.99 in the second) and the counties were so large, that the researchers were not able to attribute it to the presence of the facility. The conclusions of the report recommend a more detailed study.

Although no "patterns jump out at you", says Stone, "there are some plants that are significantly high and some that are significantly low. You do have this feeling that you should go back to certain areas [and do a more detailed analysis] because you feel uneasy." Given the uncertainties in the NCI report and the interest of Senator Edward Kennedy, one of the chief backers of the study, a further project appears likely.
Roberts says that UCL finds it "singularly difficult to persuade British companies to put money into bricks and mortar". Little money for new buildings is forthcoming from government, through the Universities Funding Council, so the best option for universities wishing to expand their research facilities is to interest overseas companies. UCL already hosts a pharmacology research centre funded by the Swiss company Sandoz, which opened in 1985. Sandoz leases laboratory space from the college, providing money that has allowed the chemistry department to move to a new building.

Professor David Smith, from the University of Oxford's pharmacology department, another beneficiary of major overseas investment, is also disappointed with the response of British industry. In the mid-1980s, faced with declining government funding, his department began looking for increased industrial sponsorship. But Smith says that of 23 companies that attended a workshop in 1986 to hear about the department's work, only two were British. The Oxford department eventually signed a seven-year $£ 20$ million agreement with the US company Squibb (now Bristol-Myers-Squibb) in 1987, to finance a new building for the department and run a number of research projects. Under the Oxford-Squibb arrangement, researchers are not Squibb employees. Squibb files for any patents on the results of research, but the university receives a royalty on any commercial gains.

UK pharmaceutical companies argue that they already contribute to the British universities through the tax system, and point out that companies - both British and foreign - like to be seen to be supporting local research when they are operating in overseas markets. As an example they note that the British company Glaxo last year provided $£ 15$ million to set up a neurosciences centre at the National University of Singapore for research into dementia and Parkinson's disease.

For overseas companies, there is also a direct financial advantage that may offset investment in UK universities: drug companies may charge the National Health Service more for their products if they have substantial research activity in the United Kingdom. British companies have no such incentive to invest in university research.

But there does seem to be some genuine dissatisfaction within the British pharmaceutical industry over arrangements for research in UK universities, John Griffin, director of the Association of British Pharmaceutical Industry, last week told the British Pharmaceutical Conference in Cardiff that universities are charging inflated overheads on research contracts to subsidize 'lame duck' departments. 